\title{
Urban qualities and residents' strategies in compact global south cities: the case of Havana
}

\author{
María José Zapata Campos ${ }^{1}$ (D) . Jaan-Henrik Kain ${ }^{2} \cdot$ Michael Oloko $^{3}$. \\ Jenny Stenberg ${ }^{2} \cdot$ Patrik Zapata ${ }^{4}$
}

Received: 6 July 2019 / Accepted: 20 April 2021 / Published online: 6 May 2021

(c) The Author(s) 2021

\begin{abstract}
Research and policy argue for more compact cities to respond to sustainable development challenges. However, what actually needs to be made more compact and how, is under examined, particularly in global South cities where north notions of urban qualities are adopted without being questioned. Informed by a qualitative study in informal and compact neighborhoods in Havana, this paper explores which qualities are important to deliver more just cities, and what strategies are developed by residents to strengthen beneficial qualities and address detrimental qualities in contexts of informal urbanization and compactness. It shows how the street, human capital, neighborhood, housing affordability, citizenship and vibrancy are significant compact city qualities neglected in the literature. Finally, the paper shows how diverse strategies are developed by residents to draw upon these qualities, such as self-help urbanism, learning and innovation, economic entrepreneurship, networks of solidarity, economies of reciprocity, local imaginaries and active citizenship.
\end{abstract}

Keywords Compact cities · Density · Informal settlements · Housing · Public space · Neighborhood

María José Zapata Campos

mj.zapata@handels.gu.se

Jaan-Henrik Kain

kain@chalmers.se

Michael Oloko

moloko@jooust.ac.ke

Jenny Stenberg

jenny.stenberg@chalmers.se

Patrik Zapata

patrik.zapata@gu.se

1 School of Business, Economics and Law, University of Gothenburg, PO Box 610, 40530 Göteborg, Sweden

2 Department of Architecture and Civil Engineering, Chalmers University of Technology, Göteborg, Sweden

3 Jaramogi Oginga, Odinga University of Science and Technology, P.O. Box 210-40601, Bondo, Kenya

4 School of Public Administration, University of Gothenburg, Göteborg, Sweden 


\section{Introduction}

Both researchers (e.g., Breheny, 1996; Brugmann, 2009; Churchman, 1999; Glaeser, 2011; Rueda, 2014; Westerink et al. 2013) and policy makers (e.g., European Commission, 2011; OECD, 2012; UN-Habitat, 2012; UNEP 2013; EEA-FOEN 2016; United Nations, 2017) argue for compact cities as a response to social, ecological and economic challenges mostly experienced in cities with high densities, diversity and mixed use. However, there is little clarity and/or agreement on what aspects of a city actually need to be made more compact to achieve the purported benefits (Boyko \& Cooper, 2011; Neuman, 2005). This is especially the case for informal settlements in the Global South, where generic, North notions of urban qualities driven by international development agencies are seen as standardized recipes to prompt development and fight poverty (e.g. UN-Habitat, 2012, UNEP, 2013). Such recipes typically involve strong capacity for exercising state control to safeguard the distinction between built and unbuilt areas, available financial resources to heavily densify expensive central areas and to build effective public transport systems, and reduction of plot sizes in more peripheral areas to meet density targets (Du Plessis \& Boonzaaier, 2014; Watson, 2002). If applied without thorough considerations for local specificities, they may be detrimental to positive urban change (Dave, 2011) since compact city policies need to be contextualized (Bardhan et al. 2011; Watson, 2002) in order to better reflect how compactness can improve residents' livability (Mouratidis, 2017).

Despite this need to understand how different contexts affect the social, environmental and economic sustainability of the communities in compact cities (Dempsey \& Jenks, 2010), most research in this field is limited to Global North cities (Kain et al. 2020), neglecting that most of the urban expansion is taking place in developing countries, and more particularly in highly dense informal settlements (United Nations, 2017). Compact informal settlements are often characterized not only by a deficient provision of infrastructures and services, but also by an extensive informal sector providing housing, water, sanitation, energy, transportation, waste collection, food and other services. Rather than being treated in isolation, informal settlements, their problems and solutions, are part of the urban fabric in what has been coined as the logic of informal urbanization (Roy \& AlSayyad, 2004). This logic permeates everyday life and becomes the soil for grassroots social innovations. The literature on informal urbanization and social innovation reminds us that compact informal settlements, beyond their physical qualities, are characterized by informal economic services, learning and entrepreneurial processes (Gibson-Graham and Roelvink, 2009).

Nevertheless, how compact cities qualities are shaped and how such qualities shape human, social and cultural capital, as well as informal economy, is not sufficiently addressed in the current literature. This could be explained by the dominance of a more physical and quantitative research tradition in the definition of the compact cities research agenda, leaving other qualities, such as social life and informal economic flows under researched (Kain et al. 2020). Here, a "quality" denotes an aspect or condition that can be positive or negative, and brings both benefits and challenges.

This paper aims to fill this gap and contributes to examine compact city qualities in the context of informal urbanization processes informed by the case of Havana, Cuba, and expand our understanding of these processes in the Latin American region and in the setting of a socialist society and economy. The objectives are to a) contribute to the understanding of which urban qualities are important in a compact city in the Global South to deliver more sustainable and just cities, and b) explore what strategies are developed by 
residents to strengthen beneficial qualities and address detrimental qualities in contexts of informal urbanization and compactness.

The paper is informed by in-depth interviews, complemented by visual reporting and site observations. Interviews are with residents of informal and dense neighborhoods in Havana, Cuba, and cover housing careers and life stories. Theoretically the paper builds on the literature on compact cities (e.g. Boyko \& Cooper, 2011; Frey, 1999; Jenks \& Burgess, 2000; Westerink et al. 2013), urban informality (Roy \& AlSayyad, 2004) and social innovations and community development (Appadurai, 2001; Moulaert et al., 2009; Moulaert et al., 2010). The next section develops the theoretical approach used to analyze and discuss the data, followed by the methods used to collect this data. The paper continues with a discussion of the main findings and concludes with reflections about the role of government and planning in contributing to more just compact informal settlements.

\section{Theoretical background}

\subsection{Compact cities in the global south}

The United Nations and other global agencies have endorsed the compact city model as a recipe to reduce poverty and induce development. UN-Habitat argues that 'housing, employment, accessibility and safety (...) are strongly correlated to urban form' (2012:13), claiming that more compact cities will bring prosperity and social cohesion, and minimize negative external impacts. On the same note, UNEP concludes that 'compact, relatively densely populated cities, with mixed-use urban form, are the most resource-efficient settlement pattern' (UNEP, 2013: 6). The World Development Report maintains that 'density makes the difference' (World Bank, 2009:211) for economic concentration.

Support for urban compactness has gained ground also in the scholarly literature, with arguments that it promotes resource efficiency and new technologies, saves rural land, reduces consumption of fossil fuels, increases accessibility, brings down infrastructure costs, leads to better quality of life, results in innovation and economic development, strengthens social cohesion, generates employment opportunities, and improves the quality and affordability of housing and travel (e.g., Dewar, 2000; Jenks et al. 1996; Keiner et al. 2004; Satterthwaite, 2010). Strengthening compact city qualities, such as public transport, access to urban centers and mixed land use, has been seen to positively affect residents' perceptions of livability (Mouratidis, 2017). In contrast, research has also shown how more compact cities can lead to crowding, unaffordable housing, inequity, health problems, congestion, pollution and loss of green space (Dave, 2011; Echenique et al. 2012; Neuman, 2005). Still, some commentators contend that compact urban form, at least partially, correlate with social benefits (Bramley et al. 2009) and social justice and equity (Bardhan et al. 2015; Burton, 2000).

The notion compact city is largely born as a Eurocentric paradigm (Dempsey \& Jenks, 2010; Shirazi \& Falahat, 2012; Watson, 2002), and most of the literature on compact cities deal with the urban contexts of the Global North (e.g., Jabareen, 2006; Boyko \& Cooper, 2011; Kain et al. 2020; Larco, 2016; Ahlfeldt \& Pietrostefani, 2019). Although compactness does not necessarily mean low quality in public spaces and small accommodation (Patel, 2011), it may be questioned whether increased density is the best recipe in Global South cities that are already characterized by high densities (Kotharkar et al. 2014). As Dempsey and Jenks (2010, p.119) claim 'there is a need to examine the compact city 
in politically, culturally and geographically disparate cities in developed and developing countries' since compact city policies and programs need to be tailored to the local context in order to deliver quality of life (Bardhan et al. 2011).

A particular aspect concerns what we actually mean by 'compact'. Typically, its definitions refer to dense, walkable, well-connected areas, with mixed-land use and proximity of services (e.g., UN-Habitat, 2012). Still, the qualities of compact cities are varied and not all of them have received the same attention. Literature reviews on compact city qualities have shown how most studied qualities pertain to built structures, transport infrastructure and economic growth, while much fewer are related to issues, such as urban nature, health, quality of life, social interaction, equity and adaptability/resilience (e.g., Boyko \& Cooper, 2011; Kain et al. 2020; Ahlfeldt \& Pietrostefani, 2017). This is unfortunate, since such urban qualities may be of particular importance in dense and informal settlements of the Global South where material resources (such as buildings, infrastructure and money) may be less available. In other words, despite the considerable benefits that compact cities might represent, the way such positive effects are produced and how they link to diverse urban contexts require closer investigation. In consequence, this paper seeks to pursue a complementary theoretical approach to the understanding of compact city qualities, and in particular focusing on those that have been neglected in much of the literature.

\section{Urban informality and social innovation}

In contexts where compact neighborhoods are not planned and implemented top down by state and/or market: What do urban qualities linked to density and mixed use look like? And how do they come about? To approach these questions, the paper draws on the literature on urban informality and social innovation to supplement and nuance the understanding of urban qualities already discussed in the compact cities literature.

Roy and Alsayyad (2004) introduced the term urban informality to create a new vocabulary that captures the complexity of the life in informal settlements and serves to describe the organizing logic and the system of norms that govern processes of urban transformation. This term challenges the dichotomy formal versus informal, as well as the separation between economy and space, and instead suggests that they are intertwined. Accordingly, policies for upgrading dense informal settlements not only require addressing the built environment, but also need to improve people's wages, livelihoods and political capacity (Cavalcanti \& Li Piani, 2019; Roy \& Alsayyad, 2004). This rebuke of conventional planning and policy making mirrors the limited representation of certain compact city qualities in the existing literature as discussed above. Along the same lines, Moulaert and Nussbaumer (2009) argue that territorial and social logics are imbricated and difficult to separate, as physical capital (such as buildings and infrastructure) is embedded in the human, social and cultural capital of individuals and groups in a given community and territory. This is an important observation as, for example, bonding social capital (Putnam 2000) fashioned through strong ties (Granovetter, 1973) among family and neighbors plays a key role for "family members to accumulate other capital assets" over time (Moser, 2020, p. 6; see also Authors et al. 2020; Appadurai, 2001).

Some authors have presented the rise of the informal city itself, i.e. the creation of informal housing and associated informal infrastructures, as one of the most important social innovations in Latin American cities (Abramo, 2009). The social innovation literature discusses how spatial density can work as a catalyst for revealing alternative development 
paths, as 'urban neighborhoods spatially showcase the cracks of hope in the system', as well as 'hearths of doom and decline' (Moulaert, 2009). While informal settlements have been cut off from policy delivery systems and certain economic dynamics (Davies, 2006), they have hosted 'dynamic populations and creative migration flows which have been instrumental in (partly) revalorizing social, institutional, artistic and professional assets' (Moulaert, 2009, p. 16-17). With the example of favelas in Brazil, Cavalcanti (2017) has examined the entrepreneurial capacity among slum dwellers, and shown how proximity to both local and global markets becomes important for realizing this capacity. Along those lines, Holston (2009) in Brazil, and Roy (2005) and Appadurai (2001) in India have demonstrated how these settings can become niches for innovation and insurgent citizenship, where passive residents are transformed into active city builders through their everyday practices at the margins of the formal city with its formal economy and systems for urban planning and development. From Florida's (2002) creative class to the slums' entrepreneurial heroes (De Soto, 2000), the literature has discussed how cities, and density, can lead to creativity and innovation. However, there is reason to be seriously concerned about how discourses of self-help and social entrepreneurship in this way have been instrumentalized by neoliberal politics as a means to justify the retreat of the public and how 'this celebration of self-help obscures the role of the state and even renders it unnecessary' (Roy, 2005: 150). Roy reminds us that neither apocalyptical nor romantic views of life at slums reflect the complexity of these highly densified communities.

Furthermore, studies on social entrepreneurship show how residents of informal settlements, either individually or in groups, can draw on locally available resources to solve unmet needs, creating value out of resources not perceived as such before (Zahra et al. 2009). Informal settlements are thus from this perspective characterized by a strong endogenous economy, engaging a significant part of the residents in providing services to their own neighbors, and where life largely depends on reciprocity (Polanyi, 1957) and informal markets. Rather than following a pure market rationality of economic profit, the activities of these entrepreneurs are driven by a realignment and anchoring of their commercial and social relations to the shifting economies of their communities (Frantzeskaki et al. 2012; Gutberlet et al. 2016; Smith et al. 2017).

Based on the above, the present paper applies an analytical approach that seeks to uncover and understand a wider set of physical, economic, social and cultural compact city qualities in the Global South by applying a lens of social innovation in contexts of informality.

\section{Data and methods}

\subsection{Compact Havana}

This study examines informal settlements in the city of Havana, with a population of 2.1 million inhabitants. Although the city in itself has a population density of around 2900 inhabitants $/ \mathrm{km}^{2}$, many of its districts have densities ranging between 12000 and 20000 inhabitants $/ \mathrm{km}^{2}$ (ONEI 2016, see also Table 1) placing them within UN-Habitat's definition of dense urban environments (UN-Habitat, 2015).

The city was founded in the sixteenth century by the Spaniards, leaving behind the colonial city as a legacy, intrinsically characterized by its compactness. Until the early eighteenth century the city was largely contained within La Habana Vieja (Old Havana), but the 


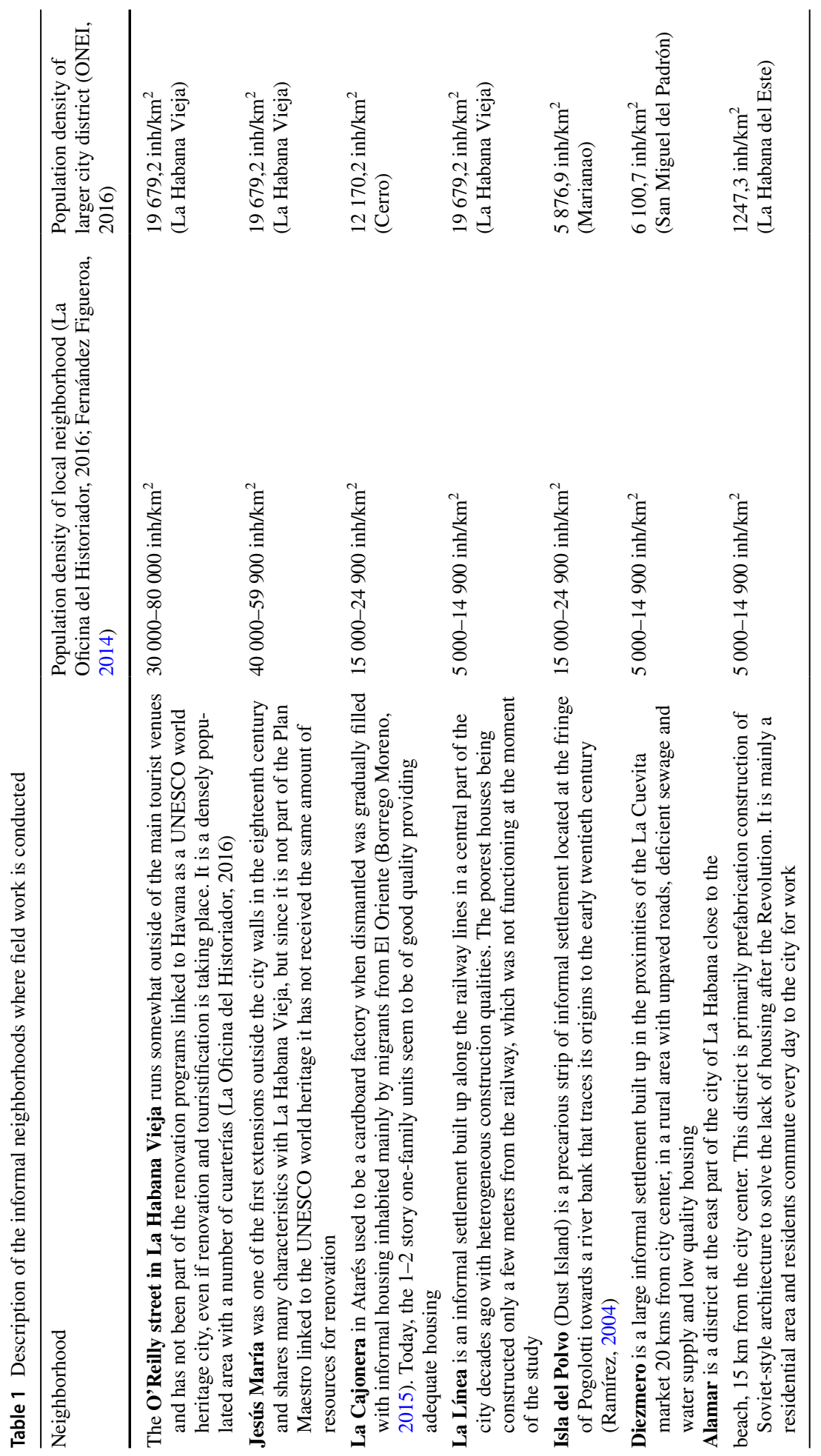


nineteenth century saw a more intense expansion outside the city walls (Alfonso González $\&$ de la Peña Gonzales, 2011). The 1920s brought a polarization period, characterized by rural-urban migration into informal settlements both in the periphery of the city and in the old city center, and the construction of upper-class neighborhoods in the periphery with lower densities (Colantonio \& Potter, 2006). At the time of the Cuban revolution in $1959,6 \%$ of the population lived in shanty towns while the rest of the urban poor lived in overcrowded subdivided derelict old mansions/houses (cuarterías/casa de vecindad) or purpose-built one/two room rental row-housing units (ciudadelas/pasajes), all of these usually with shared facilities, such as kitchen and bathroom (Coyula \& Hamberg, 2003; Ramírez, 2010).

After the revolution, new socialist policies aimed to counter the growth of the capital, promoting a redistribution of infrastructures and services within the country, and imposing a strict control of migratory movements, especially towards Havana (Ramírez, 2010). This meant that state funding for building and maintaining housing in Havana decreased, resulting in the emergence of a self-organized building sector. This informal sector has contributed two-thirds of all housing nationally in the form of new construction, additions, subdivision or conversion from other uses (Coyula \& Hamberg, 2003). Housing was also delivered through government programs, assisted by micro brigades (for example Alamar in the Havana metropolitan area) (Coyula \& Hamberg, 2003).

With the downfall of the Soviet Union and the arrival of the "special period" in the 1990s, a new wave of migration was experienced towards Havana (Santana, 2013) and this flow has continued, especially from the Eastern parts of Cuba (El Oriente) (Foresight Cuba, 2014). These flows found housing in the old city center (such as La Habana Vieja and Jesús María) where a significant share of the housing is still in the form of dilapidated cuarterías and ciudadelas (La Oficina del Historiador, 2016). Around the central city, a significant number of informal settlements (asentamientos de llega y pón, initially without formal ownership of land) are growing from this migration (such as La Cajonera, La Línea, Isla del Polvo and Diezmero), and undergoing a process of formalization when completed. Here it should be noted that the system for home ownership and the housing market in Cuba is complex and historically is quite different from other countries since the revolution (Trefftz, 2011), where ownership has been the principal form of tenure (Mesa-Lago, 2014), also in run-down cuarterías and ciudadelas, but where control over what could and should be done with these properties largely remained with the state, resulting in the prevalence of informal ways for construction and changes in ownership also in situations where formal ownership is established. Possibilities to openly sell and buy homes were introduced as late as 2011 (Mesa-Lago, 2014) and the market is currently further opening up through the new 2019 Constitution of Cuba (Anderson \& Serpa, 2018).

In La Habana Vieja, which became UNESCO protected as cultural heritage in 1982, the renovation of the built heritage and the pressure of tourist activities increased permissions for private activities (cuentapropistas), and the recently opened up housing market have resulted in processes of gentrification which may threaten housing opportunities for the urban poor (La Oficina del Historiador, 2016; Scarpaci, 2000).

\subsection{Data}

The paper is informed by in-depth interviews, inspired by ethnography studies, with forty residents living in seven informal and highly dense neighborhoods in Havana, Cuba. Precise population statistics are difficult to obtain for these neighborhoods, but the available 
data indicates population densities as shown in Table 1. As the study focuses on (at least partly) informally inhabited areas, population densities are assumed to be in the upper half of the indicated figures. Informal urban settlements tend to be denser than surrounding neighborhoods since precarious socioeconomic preconditions leads to less living space per person to increase affordability of housing.

Ethnographic interviewing is a type of qualitative research that combines immersive observation, conducted through our site observations in the neighborhoods, and directed in-depth interviews. The ethnographical method is particularly suited to studies of everyday practices. It focuses on both details - in what is said and done-and a holistic analysis of context provided by the household where the interviews were conducted. In ethnographic interviews, or contextual inquiry, the interviewer goes to the user and interviews them at the place where the user, in our case, lives. The idea is to interview residents in their natural setting, their households and neighborhoods, asking them questions along the way (Schinner, 2012).

The interviews are complemented by visual reporting and site observations. The neighborhoods were Habana Vieja around O'Reilly street (10 interviewees), Jesús María (9 interviewees), La Cajonera in Atarés (6 interviewees), La Línea and Ensenada (3 interviewees), Alamar (2 interviewees), Isla del Polvo (6 interviewees) and Diezmero (4 interviewees) (see Figs. 1 and 2 and Table 1). These neighborhoods represent informal urbanization processes in the old city centre (Habana Vieja and Jesús María), self-help settlements in central areas (La Cajonera and La Línea), informal settlements in semi-rural areas in La Habana metropolitan area (Diezmero and Isla del Polvo) and social housing, partly built by micro brigades (Alamar). The purpose of selecting a broad array of neighborhoods was to explore the complexities and variations of informal urbanization and compact city qualities in Havana. Since most interviewees were conducted among residents in city center dense areas, living in cuarterías o ciudadelas, or in self-constructed neighborhoods (La Cajonera,

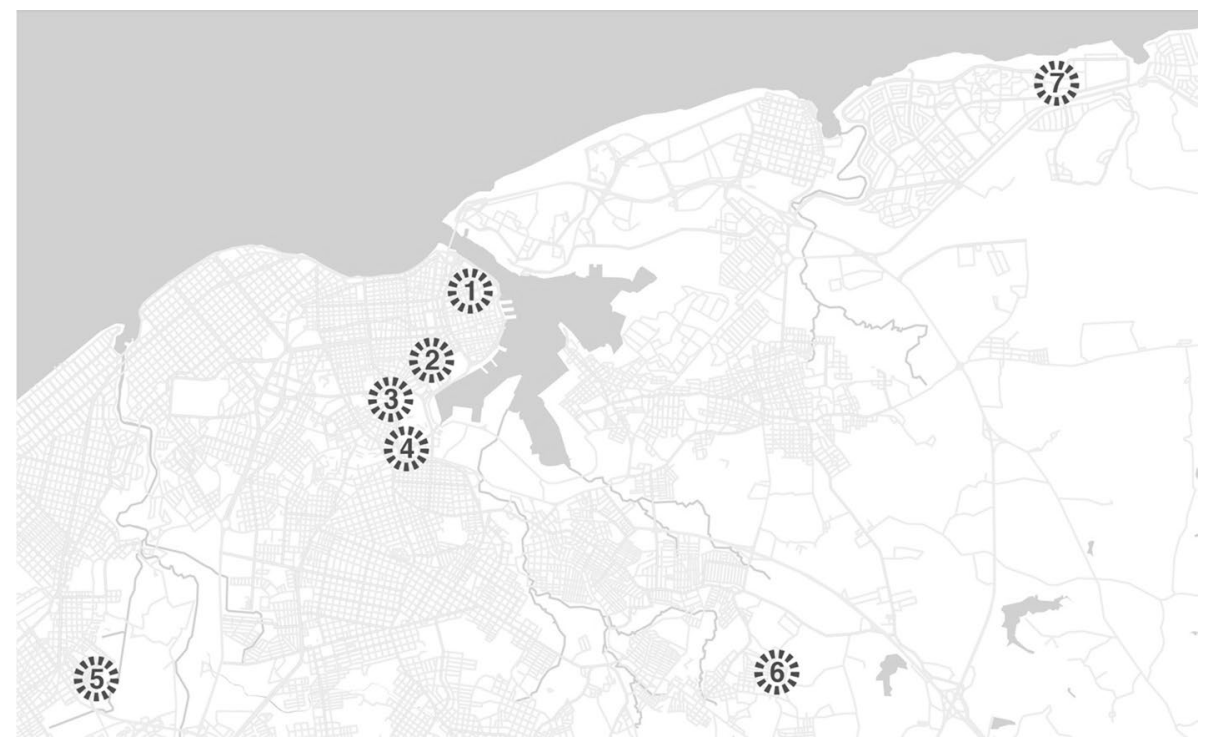

Fig. 1 Map of Havana with the visited neigbourhoods indicated: 1. La Habana Vieja around O'Reilly street; 2. Jesús María; 3. La Cajonera in Atarés; 4. La Línea; 5. Isla del Polv; 6. Diezmero; 7. Alamar. Map data (C) 2018 Google, INEGI 

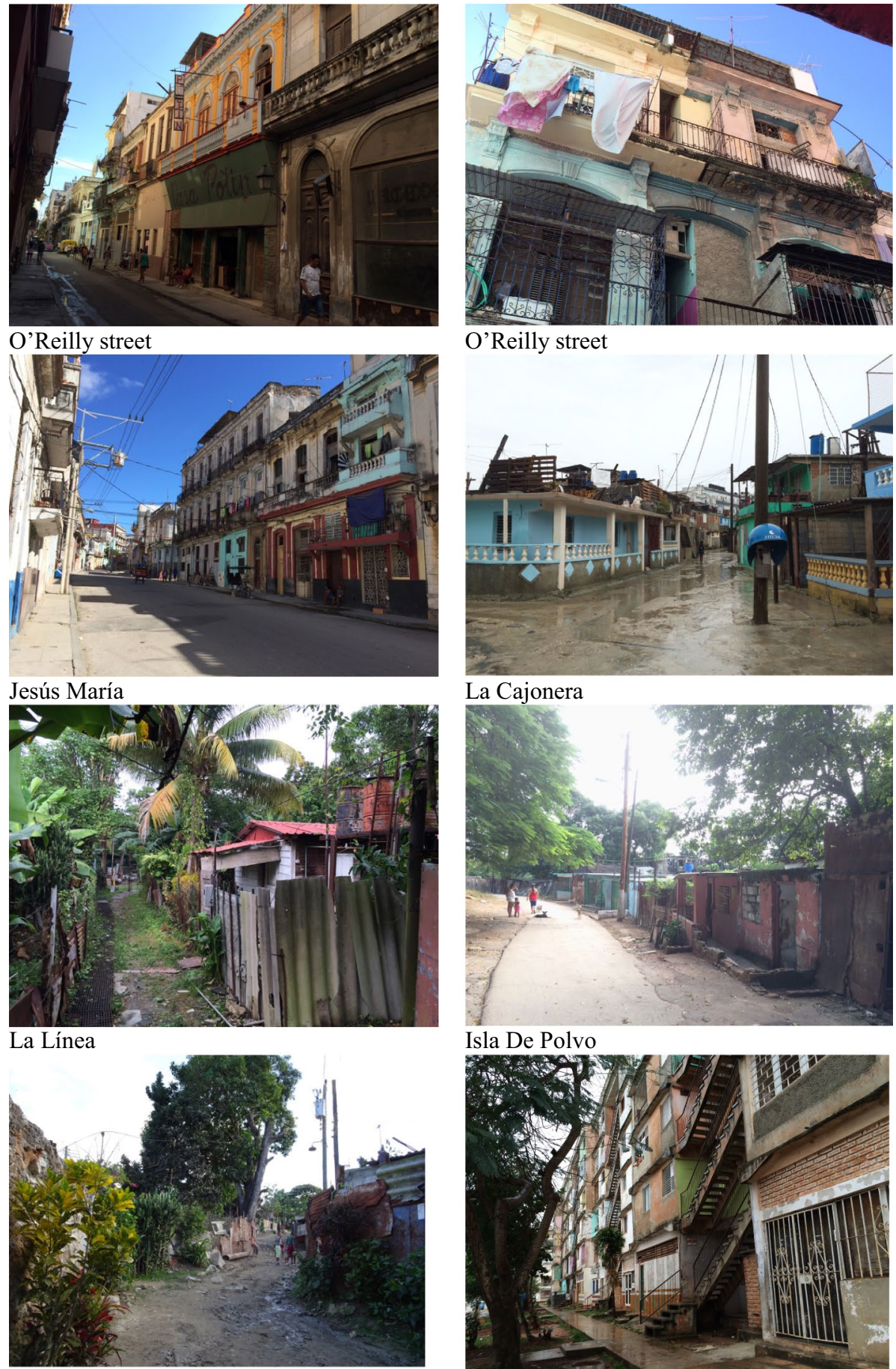

Diezmero
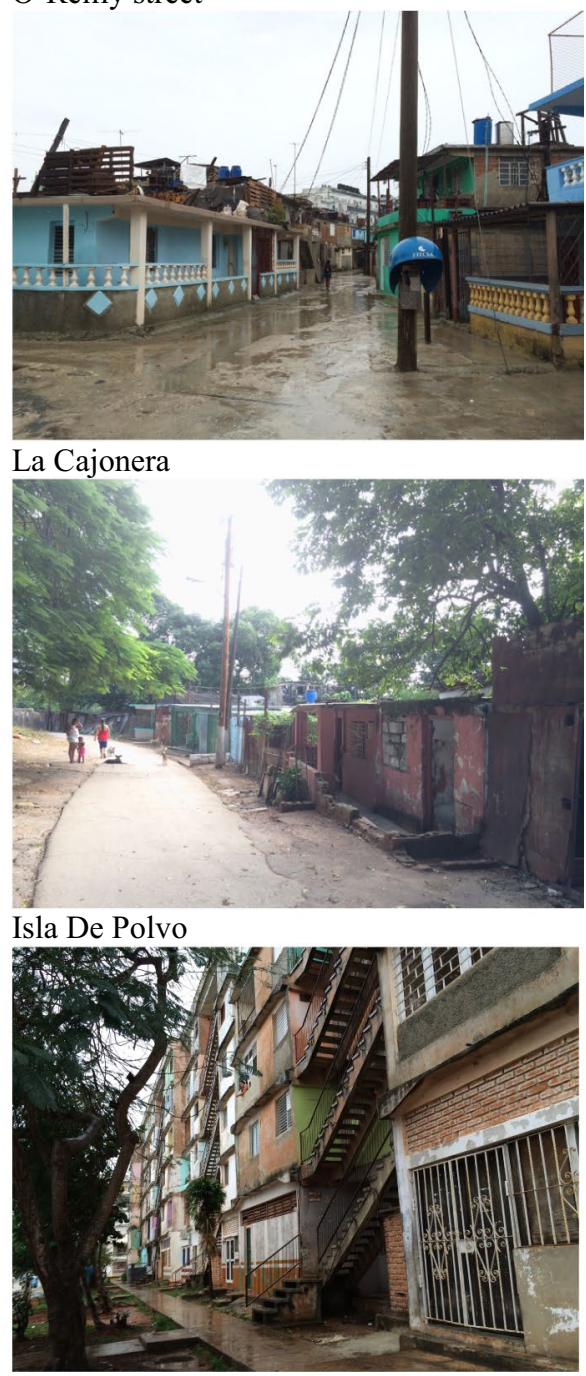

Alamar

Fig. 2 Images from the various neighbourhoods 
La Línea, Ensenada, Isla del Polvo or Diezmero), most of our findings are eschewed towards those two modalities of housing in Havana.

Out of a total of 40 interviewees, 1201 were men and 20 were women in an age range from 16 to 78 years old. The interviewees also represent different types of housing and family situations: We have interviewed people living alone, families with children, and couples, some were employees, and others were students, senior citizens or unemployed. With regard to their profession, most of them represented typical urban jobs such as municipal and state officers, casual workers, construction, clerks, and street vendors. We also had a few interviewees working with urban farming at the outskirt of the city. Many of the interviewees were immigrants from the Oriente and had not regularized their status. Moving from one neighborhood to another in their housing career was a very common feature.

As above mentioned, the interviews were mostly conducted in the interviewees' homes in order to improve our understanding of the physical qualities of their housing and conduct a situational interview whereby the interviewee can relate to the built environment to elaborate on the questions they are asked.

Some interviewees were recruited when conducting the visual observations in the neighborhood, as it is very common in Havana that neighbors stand out of their houses and talk to each other. Once inside a house block, we continued meeting other residents in the staircase, when visiting the roofs or internal gardens and meeting other residents or relatives joining our conversations. Some others were contacted randomly by knocking the door, once in the house block. After being in the same building, street or neighborhoods, the residents started getting familiar with the interviewer and this facilitated the first contact to recruit them for an interview. When interviewees were contacted, we asked the possibility to conduct the interview in their own houses, if possible, or while visiting the building in order to ask questions about their habitat in situ. After conducting a number of interviews, we tried to balance the number of men and women as well as the ages and the types of families represented in the sample to collect a more diverse representation of the residents. We also visited the neighborhoods at different times of the day to reach different groups, and not only retirees, housewives or unemployed.

The conversations focused on two main themes: urban qualities and strategies for tackling these qualities. During interviews visual observations of the house were also recorded when possible. To provide context to the interviews, document studies and site observations (audio-visual recordings, conversations) of the immediate vicinities were conducted.

The conversations started with a history of the housing career of the interviewee, their life stories and changes in their personal lives affecting the housing situation. The history also covered improvements of the housing as well as physical and social changes in the neighborhood. After this introduction, interviewees were asked to talk freely about positive and negative qualities of their housing and neighborhood. As the format was in-depth interviews, the interviewees were encouraged to include themes, such as the natural environment, critical infrastructures and services, quality of life, social and cultural life, public spaces, urban justice, and economy. The intention was to capture as comprehensive data as possible to help fill in the gaps in the existing knowledge regarding compact city qualities in informal settlements, outlined in the theoretical background above. Finally, they were asked to talk about strategies developed to build on or address these positive and negative qualities.

Interviews lasted from $15 \mathrm{~min}$ to one and a half hours, and most of them were recorded, always with the verbal consent of the interviewees. Recordings have been transcribed verbatim. The data coming from the interview transcriptions, the notes taken during the interviews as well as the site observations, were coded inspired by grounded theory (Strauss 
\& Corbin, 1990) allowing categories of compact city qualities to emerge from the stories told by interviewees. The categories were aggregated into different themes, summarized in Table 2 .

\section{Results: perceived qualities of urban compactness informed by interviews with Havana residents}

In the following, the perceived qualities of urban compactness are presented informed by the empirical material. First, we discuss physical qualities, then social, economic and cultural qualities.

\subsection{Physical qualities}

In terms of the built environment, this study identifies a number of positive qualities of living in highly dense neighborhoods in Havana: affordability of different forms of housing (free usufruct, ownership and non-legalized self-construction); proximity to jobs, critical infrastructure, services, leisure facilities, shops and food supply; safety and absence of cars; and diversity of land use. For example, a resident in Jesús María expressed the importance of proximity as a quality of the neighborhood where he lives: "The good thing is that everything is very close, I work just here (...) shops, work, food stores, it is central to go anywhere in the city, transportation, everything is there" (M, Jesús María).

Still, poor quality of housing and building maintenance; crowding within the house with the associated deterioration of wellbeing; health and lack of social discipline (noise contamination, dirt); uncertainties of living in non-legalized properties; unequal access to services by the urban poor (despite their availability and proximity); and poor waste management in the streets remain back sides of living in these compact neighborhoods. In particular, crowding and the conditions of the housing are strongly perceived as sources of stress and family conflicts, as this resident explains: "(Houses) are subdivided as the family grows and everybody lives together, and then comes the problems of co-living. (This results) in a generation clash, because you find a partner and you can't live together, there is not enough space at home. At the end, this brings problems and the relationship decays and dies" (A, Jesús María). Also mental health and well-being are seriously affected by crowding. As this female resident complains, living four generations in a very crowded apartment, together with a situation of poverty, leads to mental illness: "We have nothing. My daughter is sick in her nerves, high blood pressure. I take diazepam up to three every day, it is anxiety. I can hardly sleep" (MC, Habana Vieja). For those who live in non-legalized self-constructions, or who have made non-legalized improvements, the fear of losing their property is also a source of stress: "(The problem is) that we don't get the house's entitlement. One lives with that fear, will it be yours? Will they take it away from you after you have done so much? My husband and I have spent our whole youth building up this house!" (K, La Cajonera).

The findings also suggest that a minimum level of critical services is perceived as acceptable in certain contexts. It was noteworthy to observe how, despite a very limited provision of water (e.g., half an hour every two days) involving the mobilization of neighbors to cope with this situation, none considered this limitation to be a real concern: "We could have water daily, but what for? It is wasted unnecessarily because, I have two full tanks, the other one as well, then when the water comes it spills over. There is no need. 


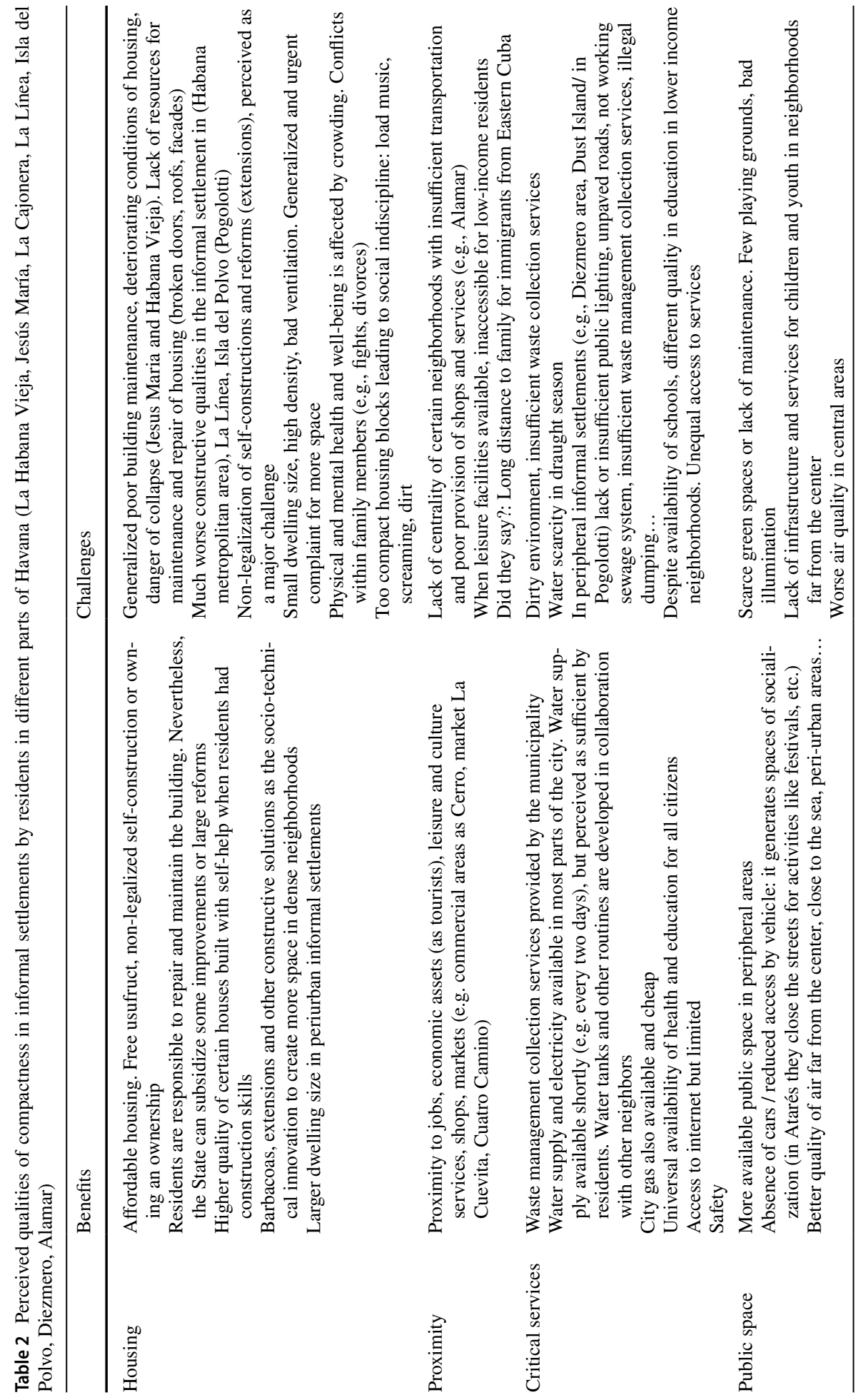




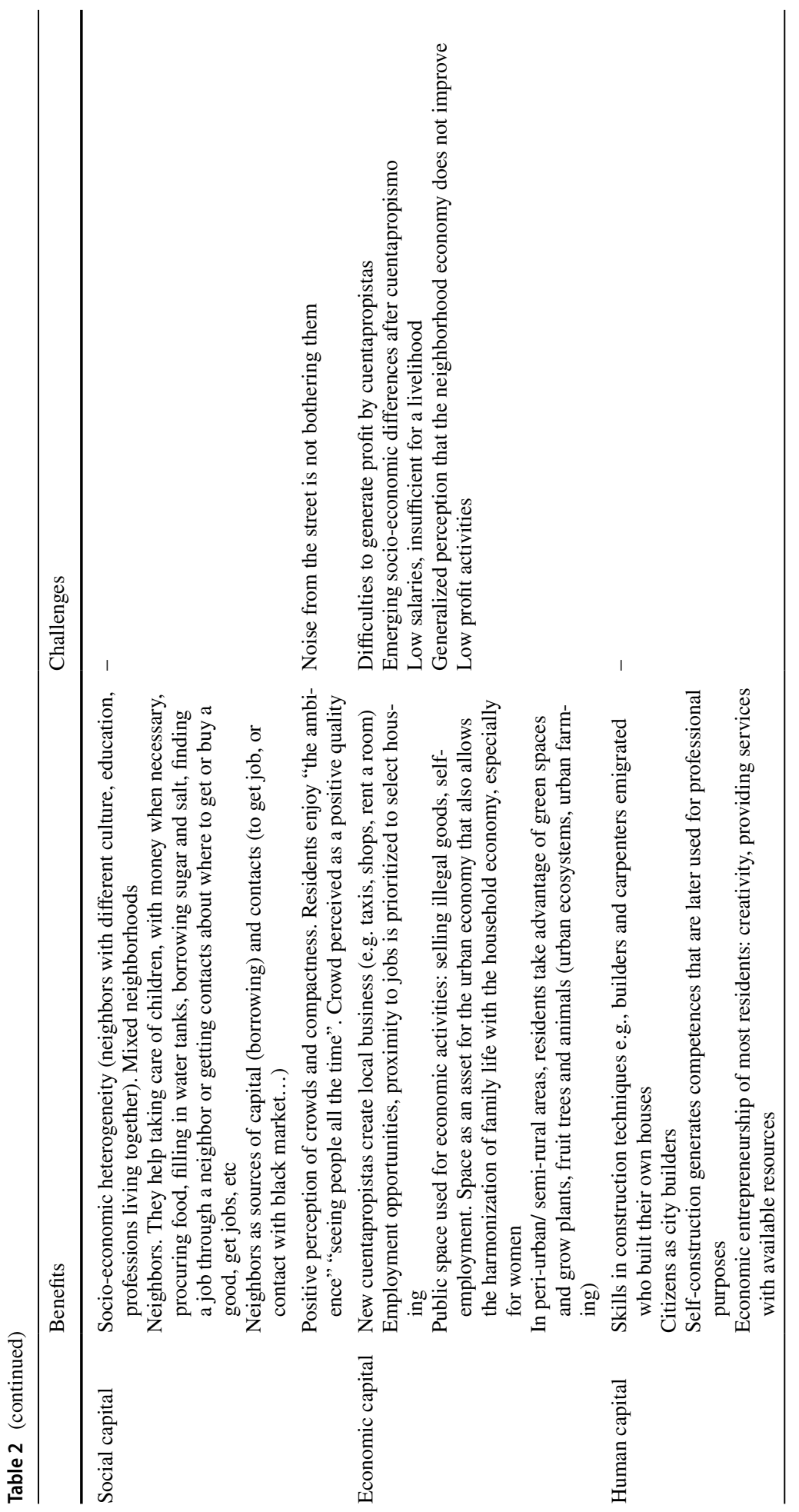




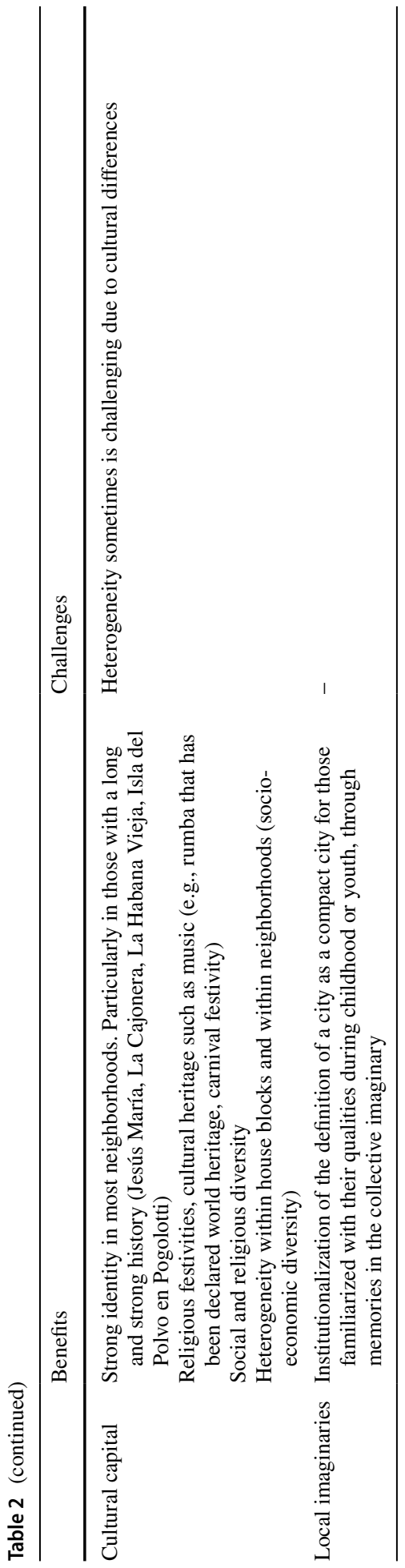


We have a water crisis in the country and we have to save water. One way to do it is to provide water in alternative days. And it works! If you administrate yourself well (it works) because you know that you are going to do the laundry today, so you have to save water" (P, Habana Vieja).

\subsection{Economic, social and cultural qualities}

With regard to more intangible qualities, the social, cultural and economic diversity of residents is perceived as an asset to cope with the material uncertainties of life in these neighborhoods. The diversity of cultures, religions, professions and education in the same space can serve as an economic asset for urban poor and improve social cohesion, solidarity and understanding between different social groups. On that note, the socialist legacy remains as an innate quality of Havana as a compact city. "There all sorts: nurses, teachers, others work in the harbor, carpenters; from all the sectors" (I\&C, La Cajonera). This broad representation of professions, cultures and religions in La Cajonera is confirmed in other neighborhoods, such as in Alamar, where one resident explains: "Here people from very different origins, cultures and religions live together" (RI, Alamar).

Regardless of all problems related to the housing conditions many residents argue they would not leave the neighborhood due to this diversity and strong identity: "Despite all the housing problems and the deterioration of the neighborhood, I would not leave this place" (A, Jesús María). Neighbors provide the necessary "moral and material support" (J\&H, La Habana Vieja) to help taking care of children, procure food, fill water tanks, help finding jobs, lend money, etc. In the words of one resident of Habana Vieja "there is solidarity, despite the differences. You are not more or less. If necessary, everybody supports despite the differences" (P, Habana Vieja).

Furthermore, in neighborhoods like La Cajonera the self-construction process has generated competences that have later been used for professional purposes: "I used to work in agriculture. I got sick and had to change job and I started as a carpenter... Family, friends helped me (to construct the house). I drew the plans. The carpentry (as a profession) started with the house" (I\&C, La Cajonera). Residents living in self-constructed houses showed pride of their earned capacities and what they have achieved themselves: "(Everything here has been built up) with own efforts. Starting with the connections (of electricity and water) to the tubes of the State... What I like is that it is my house, that we built it up ourselves without knowing... and I feel proud" (K, La Cajonera). On top of learning new skills, the self-construction process strengthens solidarity: "We built the house, we didn't know how to construct, we learnt. My husband knows a little bit of carpentry, but family, neighbors, everybody helped us" (ME\&N, La Cajonera).

Another interesting quality is the street, and how it is reconfigured as an extension of the privacy of the home diluting the boundaries between private and public space. Urban space becomes a fundamental part of the socio-economic life in the settlements, as it provides space to harmonize family life, residential and economic activities, particularly for women who, in this way, both can take care of the family and contribute to their livelihood. In the face of the absence of formal jobs and properly arranged public spaces (e.g., green areas or playing grounds as reiterated in interviews), residents make use of public space, appropriating and transforming it according to their needs. They close the streets for festivities, children play football, and single mothers sell smuggled or repackaged products in the street in front of their houses. One resident in Habana Vieja explains how she manages to take care of her son while informally selling some coffee or milk in the street where they 
live: "My husband died, I am a housewife. My son goes to school and I have to be here to prepare his lunch, and I continue with my housework... (I do) sales (street selling) sometimes when I have some milk or coffee, small things like that, from the State coupon spaghetti that I can sell" (G, Habana Vieja). Another woman from La Línea makes products based on recycled plastic bottles to sell to her neighbors: "I make gift packages for special dates... Very soon it is the Teacher's Day, I am preparing presents to sell to them... I buy shampoo in bulk and I sell it in smaller bottles in packages... That plastic flower I also make out of the small plastic bottles (reused from the hotels). Things that one just invents in one's head. The shampoo bottles come in colors, the green bottle I use for the leaves... and just here the neighbors buy them" (A, La Línea, Ensenada).

Yet another perceived quality is vibrancy, related to the flows of tourists and residents in more central neighborhoods and bonded to a positive perception of crowding in the neighborhood. Comments like "loud music from the street" (P, Habana Vieja) or "the tourists don't bother me" (J\&H, La Habana Vieja) were reiterative during our fieldwork. Perceived crowding outside the house (but not within the building or the home) therefore stands out as a positive compact city quality in the cultural, social and political context of our study: "the street is always crowded, always people on the street (it is the best), the Cuban is a human being of crowds" (A, Jesús María). This perception of vibrancy as a positive quality of crowded neighborhoods derives from the residents' perception of an ideal city being a compact space; an ideal that is internalized during childhood or youth and that remains in the social imaginary as the place to come back after moving away from these compact and central neighborhoods for different reasons: "I was born here and I feel good, I am adapted, the music doesn't bother me" (P, Habana Vieja).

\section{Discussion}

In this section, we elaborate on the contribution of this study, first to theoretical discussion linked to the concept of compact cities and then to city management and planning practice.

\subsection{Compact cities qualities and residents' strategies in global South cities}

While confirming the existence of compact city qualities revealed by previous research, this study also identifies and nuances new urban qualities, as well as strategies that residents develop to take advantage of such qualities, or to cope with lack thereof (Table 3).

First, in the absence of public spaces, lack of employment opportunities, overcrowded houses, and economically inaccessible leisure facilities, the street becomes a fundamental quality in these highly dense neighborhoods. Residents develop appropriation strategies, taking the street and transforming it as the interface between the home, the social and the economy. This finding is coherent with the concept of urban informality as developed by Roy and Alsayyad, referring to an organizing urban logic that pervades every aspect of the private and public spheres (2004).

Second, the study shows how residents, by drawing from the resources at hand (social, natural, urban, human), and networks of solidarity and economies of reciprocity (Polanyi, 1979) as we argue below, provide services to their neighbors, generate their own employment, and build up their houses and infrastructures, corresponding to what Appadurai (2001), Holston (2009) and Roy (2005) call the transformation of passive citizens into active city builders. This supports previous research showing that, unlike other forms of 
Table 3 Nuancing compact cities qualities and associated strategies

\begin{tabular}{ll}
\hline Qualities & Strategies \\
\hline Public space, the street & $\begin{array}{c}\text { Appropriating the street, for social interaction and } \\
\text { informal economy } \\
\text { Drawing on proximity to resources (both material and } \\
\text { human) } \\
\text { Luman capital (knowledge, competences, creativ- } \\
\text { ity) }\end{array}$ \\
$\begin{array}{l}\text { leading to bottom-up self-urbanism } \\
\text { lecial capital: The 'neighbour' } \\
\text { Housing affordability, crowdedness, diversity, } \\
\text { vibrancy }\end{array}$ & $\begin{array}{l}\text { Local imagineries of the ideal city } \\
\text { Urban compactness as a fluid and context-dependent } \\
\text { concept, local tailoring }\end{array}$ \\
Citizenship & Residents as agents of change, the 'politics of shit' \\
\hline
\end{tabular}

family social capital (e.g. Moser, 2020) and in certain contexts of informality, proximity and access can be key for social sustainability (Dave, 2011). The study also confirms that the diversity of activities resulting from such 'city building' is actually an effect of bottomup development rather than of planned interventions (Kong, Sui, Tong and Wang, 2015, in Bardhan 2015). Residents develop creative solutions (Moulaert, 2009) through socioeconomic entrepreneurship (Gutberlet et al. 2016, Cavalcanti and Piani, 2019) and selfurbanism (or the urbanism of self-organization, e.g. Salingaros et al. 2006) such as the barbacoa (barbecue) lofts to expand housing space in dense neighborhoods. Human capital is thus a significant emergent quality of compact neighborhoods, for example, the skills, competences and knowledge developed during self-construction or entrepreneurial activities, subsequently revalorized as professional assets (Moulaert, 2009). Learning as the engine for social innovations (Frantzeskaki et al. 2012; Smith et al. 2017), self-urbanism (or the urbanism of self-organization, e.g. Salingaros et al. 2006), and economic entrepreneurship are therefore strategies developed by residents by taking advantage of these qualities.

Third, the study identifies the role of 'the neighbor' as a social institution, and as an essential quality of compact and informal neighborhoods. By creating networks of solidarity and economic reciprocity (Polanyi, 1957)—or as (Putman, 2000) puts it by forming bonding social capital within groups and bridging social capital among diverse groupsresidents of these settlements develop coalitions of interdependent actors to cope with the material uncertainties of the city in which they live. Here, the finding that a minimum level of critical services (such as water) is seen as acceptable in contexts of solidarity networks calls into questions definitions of compactness relying on unsustainable standards of unlimited supply of resources.

Fourth, in spite of the deficiencies perceived by residents, access to affordable housing-in the form of ownership, free usufruct or informal arrangements and typically delivered or improved through self-construction-is generally observed as a positive quality in the context of low-income citizens in Havana. However, this quality has to be nuanced as the amount of living space and the physical qualities is perceived as clearly insufficient and also decaying in the last years. While housing affordability (here low prices and relative proximity to jobs) is often considered as a quality of informal settlements in global South cities, Havana and Cuba offers a specific political context, not only for self-construction but also by succeeding to provide fundamental social services (food rations, schools, health care) supporting life in such informal settlements. On the one hand, the highly centralized 
Cuban system for providing a wide range of services to the citizens can be seen as an ambitious program to develop a welfare state. Unfortunately, this program has not succeeded to fully deliver the intended services and housing provision has possibly suffered the most (Ramirez, 2005). The rigidity of the public housing sector can even be seen as a hampering factor. On the other hand, the delivered social services are providing a basic level of subsistence for a large share of the population, allowing for their productive capacity to be employed for other purposes than mere survival, such as self-construction or self-renovation of housing. Still, residents who have settled in Havana without the government's permission must collect their rations in their home municipality, which is often in the far East of Cuba. This makes such migrants more vulnerable and more reliant on informal ways of gaining their livelihood, including housing. The seemingly rigid centralized systems are however also, to some extent, quite adaptive and flexible in relation to the needs of bottom-up initiatives, e.g. through posteriori formalization of building permits. Also, different types of programs for bottom-up housing provision have, from time to time, been allowed to exist as a complement to the centralized system, such as community architects (Valladares, 2017) and the workshops for integrated neighborhood transformation (Talleres de transformación integral del barrio) (Rey, 2014), providing additional support to the self-delivery of affordable housing. All in all, housing provision remains a highly complex activity in Havana.

Fifth, the example of how outdoor crowding is seen as a positive feature of dense neighborhoods as it delivers vibrancy shows how local imaginaries of an ideal city have a strong influence on how residents perceive different types of compact city qualities. This supports previous research arguing that, in certain socio-cultural contexts, living in crowded spaces is perceived as more social and convivial (Dempsey \& Jenks, 2010), despite low living standards. Nevertheless, the appreciation of vibrancy as a positive compact city quality can be different in other cultural contexts. This finding supports previous research noting how the appreciation of compactness and crowding is contextually and culturally determined (Zhang, 2000, Bardhan et al. 2015, Arifwidodo and Perera, 2010 in Bardhan 2015) and how a compact urban form may affect quality of life differently depending on context (Jenks \& Burgess, 2000, in Bardhan et al. 2015). Shirazi and Falahat (2012) reflect upon how historical urban pathways and models in a given context can remain in the "mentality" (to use their own words), granting a social acceptability to the compact urban form. Compactness is therefore not a "fixed concept" (Shirazi \& Falahat, 2012), but rather a fluid one, we argue. However, this issue has not been explored more in depth and more placespecific research (Shirazi \& Falahat, 2012), based on empirical studies of both quantitative and qualitative nature is necessary to nuance the concept and qualities of the compact city in informal urbanization processes of the Global South.

Finally, with regard to questions related to active citizenship, the particular socioeconomic diversity that characterizes the highly dense neighborhoods in Havana is observed as a singular quality. This mixture results in possibilities for lower-income residents to draw on a bonding and bridging social capital (Putman, 2001) as discussed above, through assets procured by better established citizens and remains as a significant socio-economic and political asset in Havana as a compact and mixed city. Appadurai (2001) argues how, without falling in the trap of romanticizing self-help efforts, the urban poor turn from subjects of policy making into active agents of change by transforming their physical environment, building up their houses and infrastructures, and providing critical services to their neighbors. This is a new form of deep democracy that Appadurai calls 'the politics of shit' (2001, p.37) and Holston 'insurgent citizenship' (2009, p.245). Roy (2005) argues for the need to shift from aesthetic interventions 
to the politics of shit, where expertise is developed and appropriated by the residents of informal settlements. This study confirms the emergence of a more active dimension of citizenship in compact neighborhoods, as a compact city quality, where residents are particularly active in terms of self-construction, and economic or artistic entrepreneurship, in lines with Appadurai's 'politics of shit'. Yet, we found no indication of the materialization of this agency into more explicit participation in policy making. In spite of the high levels of entrepreneurship, no evidence is found in the interviews regarding more conventional citizen participation and engagement in planning and policy making processes.

\subsection{City management and planning practice}

The debate around how compactness affects quality of life and may lead to a just city is linked to the way compactness is defined and by whom. If policies supporting compact cities only refer to higher densities of people and buildings there is no need "of further densification ... (since) densities are already high" in many informal settlements (Burgess, 2000, p. 15). Informed by the case of Havana we conclude that there is no universal compact city recipe possible to effortlessly apply in planning and policy making to improve quality of life, as the effects are highly dependent on contextual phenomena and will vary according to factors, such as colonial legacies, the pace of the urbanization process, governance systems, and local imaginaries of ideal cities. In other words, compact cities qualities "are more relative than absolute" (Dave, 2011, p. 56). The role of local imaginaries of a 'good city' has to be included as a contextual phenomenon in order to improve planning, governance and management of informal urbanization. Along those lines, Authors et al. (2020) argue that instead of applying Global North blueprints, "compact city theories and policies need to be regionally tailored to best respond to locally specific urban contexts and development needs, especially in relation to widespread informality".

To build compact and just cities, and not 'just' compact cities (Burton, 2000), planning practices need to include mobility strategies for the urban poor, public spaces that take into account and strengthen the role of the street as socioeconomic nucleus, and support of more diverse and mixed uses. Unlike other Latin American cities, the absence of cars in some neighborhoods of Havana-for political and historical reasons-opens up opportunities for strategies that develop public space to strengthen urban qualities linked to the rich human capital, embodied in neighbor interaction and local imaginaries of urban space.

Having said that, planners need to bear in mind that people's capacities and livelihoods need to be upgraded in parallel with the built environment (Roy, 2005). Once more equal opportunities for livelihoods are in place, the upgrading of physical urban qualities may be co-produced with residents with more ease through different models of self-urbanism. In other words, a redefinition of the compact city is necessary in which qualities related to aspects of human, cultural, social and economic capital becomes a priority and where knowledge about how to create just compact cities gravitates from experts to residents as active producers of the city. Planners, policy makers and politicians would benefit from reflecting thoroughly on what policies and plans need to be implemented to obtain compact city qualities. Again, we would like to emphasize the 'hidden' qualities of the informal economy and the social innovations that take place in the informal settlements of cities. If these qualities are neglected, planning and policy making will in fact constrain the development of a just compact city (Kotharkar et al. 2014). 


\section{Conclusions}

This paper aims to fill a gap in the existing literature on compact cities, with regard to the lack of clarity regarding what qualities of a city actually need to be more compact in the context of urban informality of Global South cities, and through which strategies the purported benefits can be achieved. Informed by a qualitative study in informal and compact neighborhoods in Havana, this paper has examined which qualities are important in order to deliver more just cities and what strategies are developed by citizens to strengthen such beneficial qualities and, at the same time, address the detrimental qualities that prevail in many contexts of informal urbanization and compactness.

The study confirms the existence of certain compact city qualities revealed by previous literature while it also identifies other types of qualities linked to urban compactness. It shows how the conceptualization and use of the street; the development of human capital (in terms of knowledge, competences and creativity); the neighborhood social capital in connection to proximity, mixed composition and density; the housing affordability, crowdedness, diversity and vibrancy of the neighborhood; and the construction of citizenship, are all significant and emergent compact city qualities largely neglected in the literature. We have also shown how residents of these highly dense and informal neighborhoods develop diverse strategies to simultaneously create and draw upon these qualities. These strategies include self-help urbanism, collaborative learning and innovation, economic entrepreneurship, networks of solidarity, economies of reciprocity, local imagineraries and the construction of an active citizenship.

Our paper confirms that the concept and content of the compact city ideal is fluid and contextual. There is no universal recipe for a compact and more just city, as it needs to be adopted and translated locally according to the conditions and qualities in each setting. For policy makers and planners, this opens up opportunities for strategies that draw on, develop and strengthen urban qualities linked to the rich human capital of informal settlements, embodied in their vibrant neighbor interaction and local imaginaries of the good compact city.

Funding Open access funding provided by University of Gothenburg. This work was supported by the Swedish Research Council for Environment, Agricultural Sciences and Spatial Planning (Grant number 2015-00360).

Open Access This article is licensed under a Creative Commons Attribution 4.0 International License, which permits use, sharing, adaptation, distribution and reproduction in any medium or format, as long as you give appropriate credit to the original author(s) and the source, provide a link to the Creative Commons licence, and indicate if changes were made. The images or other third party material in this article are included in the article's Creative Commons licence, unless indicated otherwise in a credit line to the material. If material is not included in the article's Creative Commons licence and your intended use is not permitted by statutory regulation or exceeds the permitted use, you will need to obtain permission directly from the copyright holder. To view a copy of this licence, visit http://creativecommons.org/licenses/by/4.0/.

\section{References}

Abramo, P. (2009). Social innovation, reciprocity and the monitarization of territory in informal settlements in Latin American cities. In D. MacCallor, F. Moulaert, J. Hillier, S. Vicari Haddok (Eds.), Social innovation and territorial development (pp. 115-130). Ashgate, Farnham. 
Ahlfeldt, G. M., \& Pietrostefani, E. (2019). The economic effects of density: A synthesis. Journal of Urban Economics, 111, 93-107.

Ahlfeldt, G.M. \& Pietrostefani, E. (2017). The Compact city in empirical research: A quantitative literature review. In SERC Discussion Paper 215.

Alfonso González, A., \& de la Peña Gonzales, A. M. (2011). La ciudad compacta: Arquitectura y micoclima. Editorial Félix Varela.

Anderson, I. \& Serpa, R. (2018) Cuba: private home ownership recognised for first time since the revolution. The Conversation, The Conversation Trust (UK) Limited. https://theconversation.com/cubaprivate-home-ownership-recognised-for-first-time-since-the-revolution-100204.

Appadurai, A. (2001). Deep democracy: urban governmentality and the horizon of politics. Environment and Urbanization, 13(2), 23-44.

Bardhan, R., Kurisu, K., \& Hanaki, K. (2011). Linking Urban Form and Quality of Life in Kolkata, India, paper to 47th ISOCARP Congress. Wuhan.

Bardhan, R., Kurisu, K., \& Hanaki, K. (2015). Does compact urban forms relate to good quality of life in high density cities of India? Case of Kolkata. Cities, 48, 55-65.

Borrego Moreno, R. (2015). La nación desvalida. Pobreza y bene cencia pública en Cuba (1899-1930). Temas Cultura Ideología Sociedad, 54-62.

Boyko, C. T., \& Cooper, R. (2011). Clarifying and re-conceptualising density. Progress in Planning, 76, $1-61$.

Bramley, G., Dempsey, N., Power, S., Brown, C., \& Watkins, D. (2009). Social sustainability and urban form: evidence from five British cities. Environment and Planning A, 41, 2125-2142.

Breheny, M. (1996). Centrists, Decentrists and Compromisers: Views on the Future of Urban Form. In M. Jenks, E. Burton, \& K. Williams (Eds.), The compact city: a sustainable urban form? (pp. 13-35). E \& FN Spon.

Brugmann, J. (2009). Welcome to the Urban Revolution. Bloomsbury Press.

Burgess, R. (2000) The compact city debate. A global perspective. In Jenks, M. and Burgess, R. (Eds) Compact Cities: Sustainable Urban Forms for Developing Countries (pp. 9-24). London: Spon Press.

Burton, E. (2000). The Compact City: Just or Just Compact? - A Preliminary Analysis. Urban Studies, 37, 1969-2001.

Cavalcanti, A. R. C. (2017). Work, slums, and informal settlement traditions: Architecture of the Favela Do Telegrafo. Traditional Dwellings and Settlements Review, 28(2), 71-81.

Cavalcanti, A. R. C., \& Li Piani, T. (2019). Housing by people and work: Design principles for Favelas residents in economies of commerce and service. The Plan Journal, 4(1), 113-136.

Churchman, A. (1999). Disentangling the concept of density. Journal of Planning Literature, 13(4), 389-411.

Commission, E. (2011). Cities of tomorrow-Challenges, visions, ways forward. European Commission, Directorate General for Regional Policy.

Colantonio, A., \& Potter, R. B. (2006). City profile Havana. Cities, 23, 63-78.

Coyula, M.\& Hamberg, J. (2003). Understanding slums: The case of Havana, Cuba. The David Rockefeller Center for Latin American studies-working papers on Latin America.

Cuba, F. (2014). Migración interna 2012. La isla en números.

Dave, S. (2011). Neighbourhood density and social sustainability in cities of developing countries. Sustainable Development, 19, 189-205.

Dempsey, N., \& Jenks, M. (2010). the future of the compact city. Built Environment, 36, 116-121.

De Soto, H. (2000). The mystery of capital: Why capitalism triumphs in the West and fails everywhere else. New York: Basic Books.

Dewar, D. (2000). The relevance of the compact city approach: The management of urban growth in South African Cities. In Jenks, M. \& Burgess, R. (Eds.), Compact Cities: Sustainable Urban Forms for Developing Countries (pp. 209-219). London: Spon Press.

Du Plessis, D. J., \& Boonzaaier, I. (2014). The evolving spatial structure of South African cities: A reflection on the influence of spatial planning policies. International Planning Studies, 20(1-2), 87-111.

Echenique, M. H., Hargreaves, A. J., \& Mitchell, G. (2012). Growing cities sustainably. Journal of the American Planning Association, 78, 121-137.

EEA-FOEN, (European Environment Agency and the Swiss Federal Office for the Environment) (2016). Urban sprawl in Europe (Joint EEA-FOEN report). EEA Report No. 11/2016.

Fernández Figueroa, E. (2014). Sostenibilidad urbana en las ciudades cubanas, paper presented at Tercer Congreso Internacional Medio Ambiente Construido y Desarrollo Sustentable, Havana.

Florida, R. (2002). The rise of the creative class: And how it's transforming work, leisure, community and everyday life. New York: Perseus Book Group. 
Frantzeskaki, N., Loorbach, D., \& Meadowcroft, J. (2012). Governing transitions to sustainability: Transition management as a governance approach towards pursuing sustainability. International Journal of Sustainable Development, 15(1/2), 19-36.

Frey, H. (1999) Compact, Decentralised or what? The sustainable city debate. In Hildebrand Frey (Ed.), Designing the city. Towards a more sustainable urban form (pp. 23-35). London: E \& FN Spoon.

Glaeser, E. L. (2011). Triumph of the city: How our greatest invention makes us richer, smarter, greener, healthier, and happier. London: Penguin Press.

Granovetter, M. S. (1973). The strength of weak ties. American Journal of Sociology, 78, 1360-1380.

Gutberlet, J., Kain, J.-H., Nyakinda, B., Oshieng, D. H., Odhiambo, N., Oloko, M., Omolo, J., Omondi, E., Otieno, S., Zapata, P., \& Zapata Campos, M. J. (2016). Socio-environmental entrepreneurship and the provision of critical services in informal settlements. Environment and Urbanization, 28, $205-222$.

Holston, J. (2009). Insurgent citizenship in an era of global urban peripheries. City and Society, 21(2), 245-267.

Jabareen, Y. R. (2006). Sustainable urban forms: their typologies, models, and concepts. Journal of Planning Education and Research, 26(1), 38-52.

Jenks, M., \& Burgess, R. (Eds.). (2000). Compact cities: Sustainable urban forms for developing countries. New York: Spon Press.

Jenks, M., Burton, E., \& Williams, K. (1996). The compact city: A sustainable urban form? New York: E \& FN Spon.

Kain, J. H., Stenberg, J., Adelfio, M., Oloko, M., Thuvander, L., Zapata, P., et al. (2020). What makes a compact city? Differences between urban research in the global north and the global south. Scandinavian Journal of Public Administration, 24(4), 25-49.

Keiner, M., Zegras, C., Schmid, W. A., \& Samerón, D. (2004). From understanding to action: Sustainable urban development in medium-sized cities in Africa and Latin America. Berlin: Springer.

Kotharkar, R., Bahadure, P., \& Sarda, N. (2014). Measuring compact urban form: A case of Nagpur City, India. Sustainability, 6, 4246-4272.

Larco, N. (2016). Sustainable urban design-A (draft) framework. Journal of Urban Design, 21(1), $1-29$.

Mesa-Lago, C. (2014). Institutional changes of Cuba's economic-social reforms: State and market roles, progress, hurdles, comparisons. Pittsburgh: University of Pittsburgh.

Moser, C.O.N. (2020). Mothers, daughters, fathers and sons: Intergenerational family social capital and inequalities in Guayaquil, Ecuador. Environment and Urbanization. online 0956247820959026.

Moulaert, F. (2009). Social innovation. Institutionally embedded, Territorially (Re)produced. In D. MacCallum, F. Moulaert, J. Hillier \& S. Vicari Haddok (Eds.) Social Innovation. Social Innovation and Territorial Development (pp.11-24) Farnham: Ashgate.

Moulaert, F., \& Nussbaumer, J. (2005). The social region: Beyond the territorial dynamics of the learning economy. European Urban and Regional Studies, 12, 45-64.

Mouratidis, K. (2017). Is compact city liveable? The impact of compact versus sprawled neighbourhoods on neighbourhood satisfaction. Urban Studies, 55, 2408-2430

Neuman, M. (2005). The compact city Fallacy. Journal of Planning Education and Research, 25, 11-26.

Oficina del Historiador, La. (2016). Plan Especial de Desarrollo Integral 2020 (draft version). La Oficina del Historiador de la Ciudad de La Habana.

OECD. (2012). Compact city policies: A comparative assessment. OECD.

ONEI (2016) Anuario estadístico de La Habana 2015: edición 2016. La Habana, Cuban Oficina Nacional de Estadística e Información. Retrieved from http://www.one.cu.

Patel, S. B. (2011). Analyzing urban layouts-Can high density be achieved with good living conditions? Environment and Urbanisation, 23, 583-595.

Polanyi, K. (1957) The economy as instituted process. In: K. Polanyi, C.M. Arensberg \& H.W. Pearson (Eds.) Trade and Market in the early empires: Economies in history and theory (pp. 243-270) New York: The Free Press.

Putman, R. (2000). Bowling alone. The collapse and revival of American community. New York: Simon $\&$ Shuster paperbacks.

Ramírez, R. (2004). Factores Que Contribuyen Al Éxito O Fracaso De Proyectos Comunitarios. Experiencias En El Barrio Pogolotti, La Habana. Cuba. Revista INVI, 19, 182-243.

Ramirez, R. (2005). State and civil society in the barrios of Havana, Cuba: the case of Pogolotti. Environment and Urbanization, 17, 147-170.

Ramírez, R. (2010). integrated informality in the barrios of Havana. In: Hernández, F., Kellet, P. \& Allen, L.K. (Eds.) Rethinking the informal city: Critica perspectives from Latin America. (pp. 137162) New York: Berghahn Books. 
Rey, G. (2014) Del barrio a la ciudad: una experiencia de planeamiento participativo en barrios de La Habana. In Bolívar Barreto, T., Guerrero Echegaray M. \& Rodríguez Mancilla, M. (Eds.) Casas de infinitas privaciones: ¿Germen de ciudades para todos? (pp. 445-475) Quito: Ediciones Abya-Yala.

Roy, A., \& AlSayyad, N. (2004). Urban informality: Transnational perspectives from the Middle East. Lanham: Lexington Books.

Roy, A. (2005). Urban informality. Towards an epistemology of planning. Journal of the American Planning Association, 71, 147-158.

Rueda, S. (2014). Ecological urbanism. Urban Ecology Agency of Barcelona.

Salingaros, N. Brain, D. Duany, A., Mehaffy, M. \& Philibert-Petit, E. (2006) Favelas and social housing: The urbanism of self-organization. In Paper presented at the Brazilian and Ibero-American Congress on Social Housing, 2006.

Santana, N.J. (2013). Prácticas culturales, pobreza e identidades sociales. Algunas reflexiones sobre su relación en sujetos de la comunidad de Atarés- La Habana-Cuba (working paper), in: CLACSO (Ed.), Buenos Aires.

Satterthwaite, D. (2010). The role of cities in sustainable development, sustainable development insights. Boston: Boston University.

Scarpaci, J. L. (2000). Reshaping Habana Vieja: Revitalization, historic preservation, and restructuring in the socialist city. Urban Geography, 21, 724-744.

Shirazi, M., \& Falahat, S. (2012). Compact urban form, question or solution? Examining the compact city in the Middle Eastern context: Challenges and opportunities. International Journal of Urban Sustainable Development, 4, 246-259.

Skinner, J. (2012). The interview. An ethnographic approach. Berg.

Smith, A., Fressoli, M., Abrol, D., Around, E., \& Ely, A. (2017). Grassroots innovation movements. London: Routledge.

Strauss, A. L., \& Corbin, J. M. (1990). Basics of qualitative research: Grounded theory procedures and techniques. Thousand Oaks: Sage Publications.

Trefftz, E. (2011). 50 años de la ley de reforma urbana en Cuba: En el aniversario del cambio de paradigma. Revista INVI, 26, 19-62.

UN-Habitat, . (2012). Urban planning for city leaders. UN HABITAT.

UN-Habitat, . (2015). A new strategy of sustainable neighbourhood planning: Five principles. UN HABITAT.

UNEP (2013). Integrating the environment in urban planning and management: Key principles and approaches for cities in the 21st Century United Nations Environment Programme, Nairobi.

United Nations (2017). Resolution adopted by the General Assembly on 23 December 2016: 71/256. New Urban Agenda. New York: United Nations.

Valladares, A. (2017). Successes and failures of participation-in-design: Cases from Old Havana. Cuba. Frontiers of Architectural Research, 6, 401-411.

Watson, V. (2002). The usefulness of normative planning theories in the context of Sub-Saharan Africa. Planning Theory, 1, 27-52.

Westerink, J., Haase, D., Bauer, A., Ravetz, J., Jarrige, F., \& Aalbers, C. (2013). Dealing with sustainability trade-offs of the compact city in Peri-urban planning across EUROPEAN city regions. European Planning Studies, 21, 473-497.

World Bank. (2009). World development report 2009: Reshaping economic geography. World Bank.

Zahra, S. A., Gedajlovic, E., Neubaum, D. O., \& Shulman, J. M. (2009). A typology of social entrepreneurs: Motives, search processes and ethical challenges. Journal of Business Venturing, 24, 519-532.

Publisher's Note Springer Nature remains neutral with regard to jurisdictional claims in published maps and institutional affiliations. 